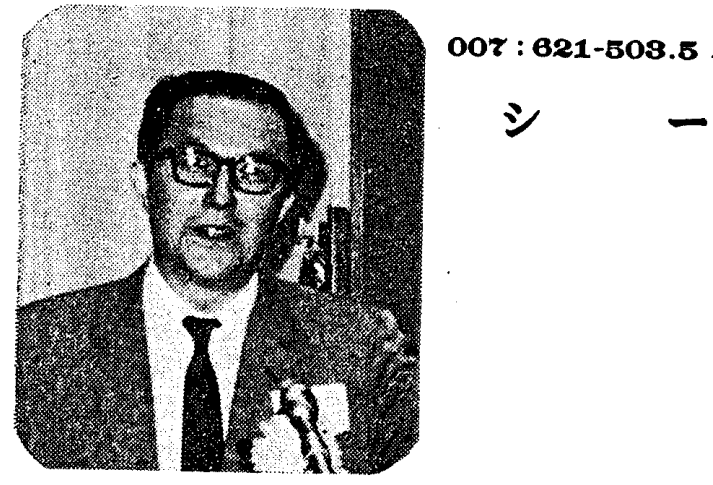

1. はじめに

言葉が持つ意味を正しくはあくすることは非常にむ すかしい，日頃使いなれている国語においてさえもそ うである.まして外国語の単語が表している内容を正 確に知ることは不可能に近い.旁菜というものは実に 長い歴史を背負っているものであって，その背累とな っている文化を抜きにしては，本当の意味がわかろう はずはないまま同時に曾莱というものは生きもので あって，しょじょにではあるが，それが意味する概念 は変化してゅくものである.

ここで垔語について論じるつもりはもうとうないの だが,このような書き出しをしたのは, シーケンスと いう英語が意味する内容を私自身がどこまできちんと つかんでいるかどうかと反省してみた結果，いかにも あやふやで，この点を前もって升解しておきたいから である.

とにかく，以下は客観的事実や証明ずみの真理の解 説ではなく，私のドグマないしは単純な感觉にもとづ いた一つの見方として受けとってほしい.

\section{2. シーケンス・プログラム・プロセス}

似たような票菜を英語の中からひろいだしてみよ う. sequence, series, succession, また process, program, progress, これらのうち, いち ばん日本語として同化されているものはプログラムで はないかと思われるが，その意味には，計画 (表), 次第, 予定, 計画……という訳からもうかがえるよう に,どことなく人間の意志のにおいがする.

ところが，プログラムが人間が意図した順序立てで あるのに対し，同じ順序という意味を持っているとし ても, シーケンスのほうは客観的な感じがしてならな い.その順序というものが，人間がもくろんだもので あろうと，天の必然性ないしは自然のなりゅきでそう なった場合であろうと，そのようなことは不問とし

*原稆付昭和 49 年6月11日.

** 正员，(束京部目照区大同山 2-12-1，同学).
ケ

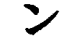

$\pi^{*}$

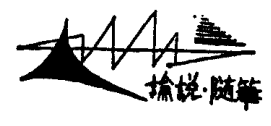

東京工業大学 教授 森 政弘**

て,クールに順序というものを指示しているように思 われる。

sequence の接頭辞の seには，「はなして」とか 「別に」とかという意味があるようであって, program の接頭辞 proが「前へ」を意味しているのと対比し てみると, シーケンスとプログラムの差異はなんとな くわかるような気がする，ある英和辞書には， sequence に対する訳の一つに，因果的連鎖というのが出 ていた. 私はこの訳こそが本特集号の主題「機械とシ 一ケンス」のシーケンスの意味にピッタリのものと思 っている. どうやら「シーケンス」とは, その一つ一 つの要秦は互いに独立したかたまりのものであって， それらが何らかの関係にもとついて配列されたつなが りを言ららしい.

ここで自動制御の世界で使われている，この関係の 用唔一シーケンス制御・プログラム制御・プロセス 制御一にについて，私なりの祱明をしておきたい。シ 一ケンス制御とは，たとえば，電気洗たく機に見られ るように，ます，(a) 水と洗用を入れ，ついで (b) 水を 止めてモータを駆動してかくはんし，(c)よごれた液を 排出し，ついで (d) 水を流しつつモータをかけてすす ぎ,さらに（e）その水を排出し，最後に（f）脱水乾㷄 する，というふうに，それぞれ独立した異なった作業 を順次進めてゆく制御のことを票っている.そして, この(a)-(b)-(c)-(d)-(e)-(f)という連鎖をシーケンス と雲うのである.これに対してプログラム制御とは, 染色そうの温度制御にみられるように, 温度なら温度 という，一つの同質の惶関して，あらかしめ時間的 変化 (曲線) を定めておき—つまりプログラムして おき—，そのとおりにその量を変化させてゆこうと する制御のことを指している.つまり，シーケンス制 御が不連綍 (discrete) な独立した異啠の作業の臬鎖 に開する制御であるのに対し，プログラム制御は同質 の連統旦の制御のことを文っている. もちろんプログ ラム曲線には不連統部分が出現することも多いが，そ の不連綍は discontinuous という意味の不連繶であっ て, discrete というものではない. 
プロセス制御というのはこれらとはまったく異な るものである. 更葉だけをとらえて直訳すれば，これ は前二者と同類同次元のもののように受けとられる ことになる一一事実時々そのような解解をまねいてい る一が，自動制御界では，これ仕化学反応装置ない しは化学反応処理工程に関する制御のことを言ってい るのである. process といら英語には，手順とか進行 という意味，ひいては，時の経過，工程という意味があ り, これから化学反応や化学的処理を行う装圈や工程 のことをプロセスと亩うようになったようであるが, そこから，化学反応処理ブロセスの制御といら意味で のプロセス制御という文莱が生まれてきたと私性推察 している.

ところで，電子計算機関係のプログラムという官葉 からは，むしろ上述のシーケンス制御といったニニア ンスが極めて強く感しられるが，一方，人間の意図に よる順序づけというにおいもふんふんとしている．声 莱はほんとうにむずかしいものである.

\section{3. シーケンスの中での拘束と自由}

图1は，有名な，ドボルザークの作曲になる新世界 交警曲第二楽章の一部「家路」のメロディの部分の総 譜である.楽曲というものは明らかにシーケンスと茟 ってよい. それは，一つ一つのおたまじゃくしで表さ れた音としてのシーケンス，音階の連鎖としてのシー
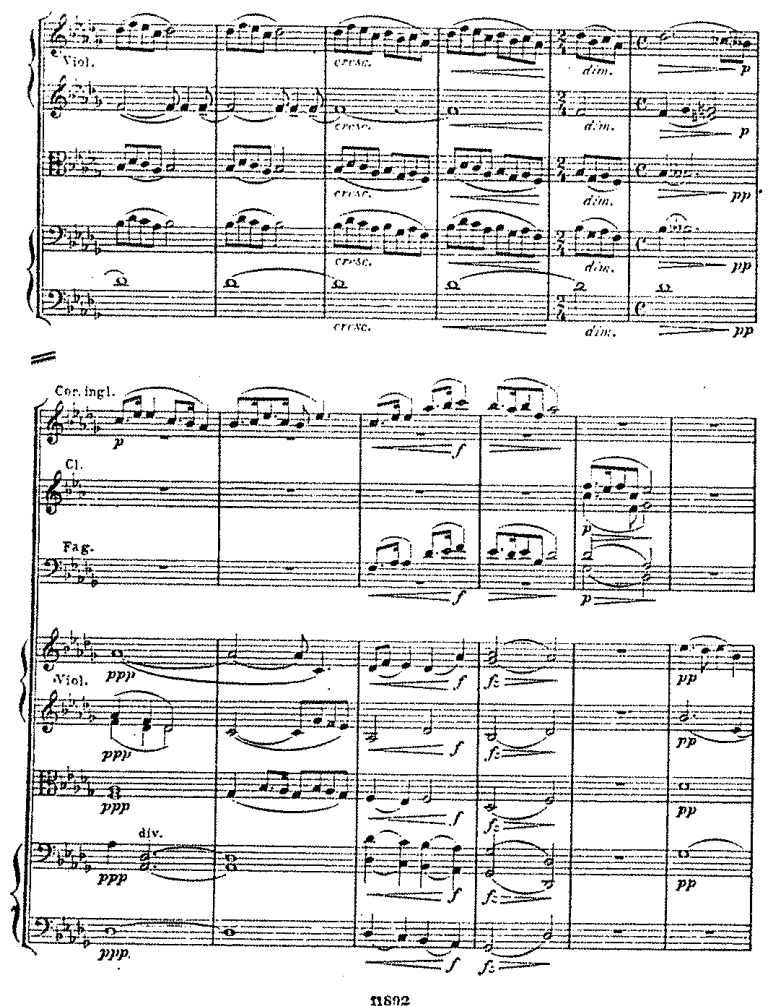

ก892
ケンス，また，異なった曲想の連鎖としてのシーケン ス（図 1 右上Un poco più mosso. の前と後では曲 が異なっている)，さらに大きくは，交響曲での楽章 の連鎖としてのシーケンスなど，さまざまのレベルで とらえることができる．ここで，上記のプログラム制 御は，、うなれば, $p<f>p$ のひとまとまりの強弱の 制御に相当するといえよう。

ここで、ひとつぶずつの音というものは，実におも しろい，どの音をとってみても，その前の音に無関係 にはその音は定まってはいない，すなわち，一つの音 の出現は次の音の出現に対して，ある程度の自由度は 残すものの，なんらかの影警あるい社束縛を与えてい る. 情報理圇で intersymbol influence (1) という概念 が使われている.これは、一つのシンボル—この場 合は 1 個の音一が定まったとき，それがどれだけ未 来のシンボルにまで影慜を及ぼすかという時間幅のこ とである.これが每の場合，その連鎖は完全不規則で， その時間的連鎖上の一点から未来の連鎖を予測すると いうことは，まったく不可能である．また，この影響 が未来永ごうにまで及ぶ場合，すべては決定的で，ど んなに遠い未来までも予測可能となる。

音楽にかぎらず，われわれが日常接している情報的 連鎖においては，この未来に対する影繁筑囲は，等で もなく無限でもない.つまり有限のものがほとんどで ある.声葉という連鎖はその適例である．適当に将来
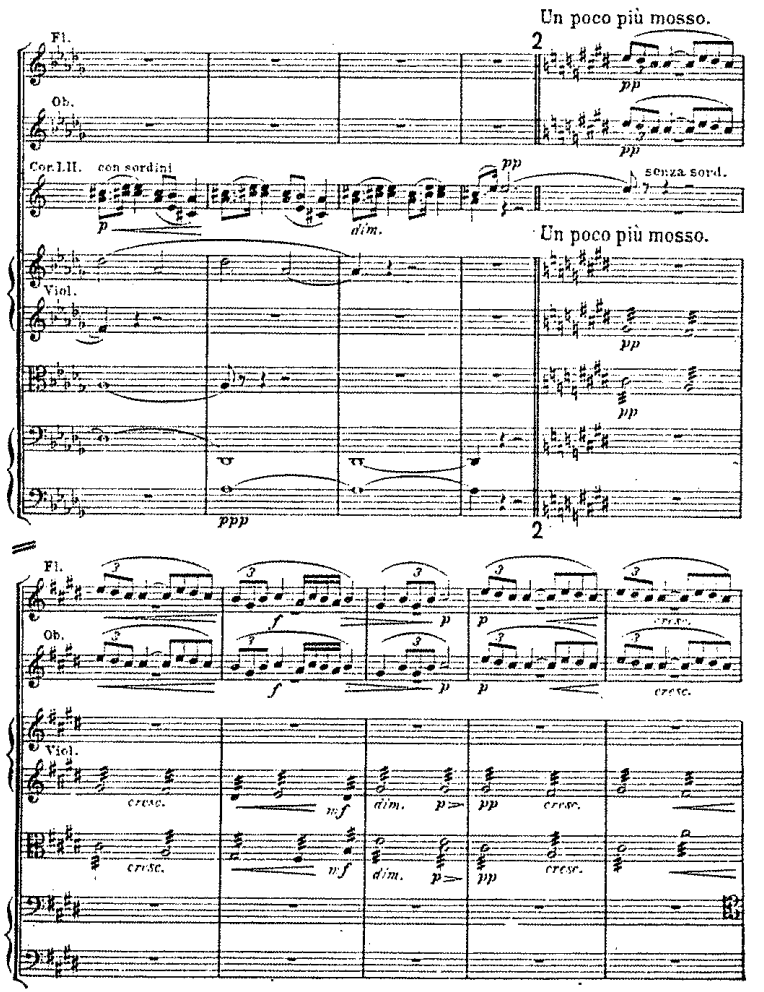

11692

图 1 ドボルザーク作曲「新世界交敏曲」第二楽章の一部（Ernst Eulenburg 版より転载） 
が拘束されているから，言葉を受け取る側である程度 の予測ができてスムーズに開くことができるわけであ り，同時に適度に未来に自由度が残されているからこ そ，言葉を発生する側に括いては表現ということが可 能になっているのである. ちなみに，表現には，考え うる多数の状態の中から一つを選定するという行為が 含まれている.

このような観方は，人生というシーケンスにもあて はまる．現時点での状態は，1２ 秒先まではほぼ完全 に，半日先までぐらいはだいたいに拘束して扔り，乙 たがってそれなりの予測が可能となって，なんとか人 生を泳いでゆけるわけである。今あなたが健康でおら れるとしたら, 1〜2 秒先はまずまちがいなく生きてい られるといえる．たとえ大地震が今急に襲ってきたと しても1〜2秒間は大丈夫である．普通ならまず今日 一日は保証できる.ところが今の状態がたとえどうで あろらと，10年先のことまではその拘束力は及ばな い.このあたりのからくりは，よくできているむのだ と感じさせられる. 1 分間先のことがまったくの不明 では，不安やるかたないことだし，生ま机たときにす でにいつ死功かかっていても，おもしろくない。 末来が不明であるといらことは，言いかえれば未来に 可能性が大きいということだわれわれはこれを逆に 錯覚してはならない。「お先まっ暗」というのは，適 当に仕組まれた拘束の有難さを忘れた不安な心理状態 であるし，「人生にはレールが敷かれている」と錯視 する䧳は，未来での可能性の存在を許す自由度が理解 できず，不満ないしはあきらめといら生命力を失った 心の持主である.

近い将来が適度に拘束されており，遠い未来に自由 が残されているといら絶妙なからくりをは沙っきりと 観て，安心と生き生きとした創造への努力を身につけ るべきである.

\section{4. シーケンスによる表現}

話を音楽へもどそう。このような未来においての自 由度のうえに, 旋律, つまりメロディの可能性がある わけである. 旋律と同程度に重要な音楽の要素として ハーモニがあることはいうまでむないところだが，旋 律はいかにもシーケンスといら感じがするのに対し て，ハーモニのほうはあまりその感じがない。ある瞬 間にいっせいにかなでられた和音ではもちろん，時間 軸に沿って並べられた分散和音についてさえもそんな ふらに思われる. 分散和音はもちろんシーケンスの範 ちゅらに入れて差し支えはないのだが，分散和音では 将来での拘束が強く自由度があまりないという点が，
こう感じさせるのかもしれない。やはり旋律は非常に 人為的な, 人間が意図したもので, 創造の可能性が多 分に秘められたものといえる.八ーモニのほうは自然 現象的で，人間があやつることのできる余地は少ない と言ってよかろう。

このことは，映画の編集にもあてはまるのではなか ろらか。 むち万ん, 映画の場合は, 一つ一つのカット は報道映画では人為的な操作のしょらはまったくない のに対し，劇映画では極めて自由ではある。だが，た とえば，どちらの種類の映画であっても，200カット なら 200 カットという同じ量と同じ内容の素材を使っ ても, 映画全体としての筋書きは, カットの並べ方, すなわちシーケンスによって極めて大幅に変化する.

言葉について見てみれば，さらに顕著である．最小 単位としてのイロ八やアルファベットの並べ方で， あ るいはその上位の単位である単語とか句の配列いかん によって，というよりも，そのことだけによってすべ ては表現されている.

このように考察してみると, シーケンスとは実に偉 大な，また恐しいものであって，ものごとの順序のた いせつさをしみじみと味わされる，閒違えたために失 敗したという例は極めて多い.

\section{5. 製作とシーケンス}

ものを作るという行為をながめてみると、ごくおお まかにいって，切るといら作業と結合するといら作用 のシーケンスから成り立っているように考えられる。 その証拠に，工具や工作のための機械は，切るための ものと結合するためのものとに大別できる. むちろん 作るための補助的ないしは間接的な測定とか保持とか のための機械・器具もあるわけだが，それら淔接的 なものではないので, いちおう無視すれば，のこぎり， かんな，旋盤などは切るためのものであり，びょう打 機, 溶接機, 圧入機などは結合するためのものである. 塑性加工も微視的にながめれば，切ってつないでいる といえる，化学反応も原子レベルで考えれば例外では ない。

昭和 48 年 3 月号の本誌「結合特集号」(2)の中で私は こんなことを述べた．単体と単体が有機的に結合する と，できあがった複合体は，それを構成している単体 が持ちあわせていなかった新しい性質を発現するよう になる.このことは，素粒子が結合して原子になり， 原子がつながって分子になり, 分子が重合して高分子 になり,さらには, 生体高分子, 単細胞生物, 多細胞 生物，……元発展している事実を見れば明りょうで ある.そして，複合体が切られて単体にもどり，それ 
ら単体が別の仕方によって結合されると，そこに新し いものが生まれる，世界の秩序は，この切り方と結合 の仕方いかんによって方向ゔけられてゆく.

“ Only change is unchanging." ただ変わるとい うことだけが不変であって，それ以外のすべては変化 してゆく.このことは最近アメリカで言われだしたこ とではあるが，われわれ日本人にしてみれば, 1000 年 以上も昔から，諸行鱓常の語によって，教え継がれて きている宇宙観である.もし，すべてのものが変化を 止めれば，それは永遠の死を意味する。変化があれば こそ流動があり，流動があればこそ生命があり，創造
もありうる.シーケンスはその過程であり，命の証左 であって，切断と結合のシーケンスとしての工程は宇 宙の大生命の一つのあらわれと観しららる。機械工学 者は，謙虚でなくてはならないが，自信をもって新し い機械をたゆまず創り続けるべきである。それが生き るということである。

\section{文献}

(1) Goldman, S., Information Theory, (1953), 17, Prentice-Hall.

（2）森，機誌，76-651 (昭 48-3)，315.

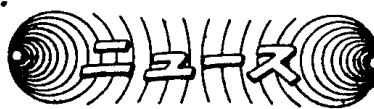

エネルギ政策中間報告（その1）
石油危機を契機に一変したわが国のエネルギ事情を 総合的に見直している総合エネルギ調查会は，このほ ど総合部会（有沢広巳部会長）を開き，エネルギ政策 に関する中間報告をまとめて中曾根通産大臣に提出し た. 報告の骨子は(1)これから昭和 60 年度にかけての 一次エネルギの総供給可能量の伸び率は過去 10 年間 の平均 (年 $12 \%$ ) を大幅に下回わり 5 〜 \% 台にとど まる，(2)安定供給確保のため海外依存度と石油依存度 を減らして行くべきだが，輸入石油は 60 年度でも一 次エネルギの $61 〜 64 \%$ (47 年度は $74.7 \%$ ) 程度を占 め，依然最大の比率を占める，(3)このため，省エネル ギ形の産業構造の形成，エネルギ利用の効率化，民生 用エネルギの節約を総合的に進めるべきだ一一な゙ で，エネルギ事情の変化に対応した政策の全面的な手 直しが必要であると強調している，同調查会は引き続 き一次ェネルギの需要分析に入り，需給両面を一本化 した最終的なエネルギ政策の答申を 50 年初めごろ通 産大臣に行う方針である。

中間報告は「エネルギ政策の前提と課題」，「第一次 エネルギの評価とその供給可能量試算」,「安定供給確 保のための総合エネルギ政策の推進」の3章から成 り，石油依存度と海外依存度が極めて高いわが国のエ ネルギ供給の実態，国民福祉の向上を図るための供給 の確保の必要性などを踏まえて分析を進めている.

その結果, 脱石油, 脱海外依存に向けて国産エネル ギの確保が重要であるとして，たとえ多額の費用がか かり多少コスト高になっても水力発電を推進するな ど, 水力, 地熱, 国内石炭, 国内石油天然ガスといっ た国産エネルギの確保とそのための国民的合意の形成 を要望している。

同時に原子力を安定的に一次エネルギとして準国産 に位置づけ，輸入エネルギでは LNG（液化天然ガス） をもっとも安定供給が期待できるとして原子力ととも に高く評価している.

総合部会は一次エネルギの供給可能量の試算を行っ ているが，その年平均伸び率は 55 年度で 5.7〜 7.6\% (48 年度基準, 石油換算 $5.5 \sim 6.2$ 億 $\mathrm{k} l$ 程度), 60 年
度で $5.7 \sim 7.8 \%$ （同 7.3〜9.2 億 $\mathrm{k} l$ 程度）と見込ま れる。

しかし，エネルギ消費の GNP 弾性値（経済成長 1 に対するエネルギ消費の割合）が現状の 1.18 1.10 程度だと経済成長率は $5 \%$ 前後にしかならず，失業の 心配のない $7 \%$ 程度の成長を実現するには弾性值を， 0.8 程度まで低下させる必要があると指摘している。

加えて, 脱石油を目標としてはいるものの輸入石油 は 55 年度で $4 \sim 4.5$ 億 $\mathrm{k} l$ 程度, 60 年度で $5 \sim 6$ 億 $\mathrm{k} l$ 程度という試算が出ているところから，安定供給確保 には需要面での省エネルギ化が必要と強調, 引き続き 調查会で検討したいとしている.

さらに，総合的エネルギ対策を推進するには（1)エ ネルギ産業の体制整備，(2)無公害新エネルギなどの技 術開発，(3)環境立地対策——などが必要であるとし， 国の積極的な政策展開を求めている。

第 1 章 [エネルギ政策の前提と課題]

（1）エネルギ供給をめぐる内外情勢の変化

i）日本のエネルギ需要の伸びは，昭和 47 年度まで の 10 年間に年平均 $11.9 \%$ と世界全体の同 $5.4 \%$ の 2 倍以上であった。 しかも 47 年度のエネルギ供給のう ち海外依存度は $86 \%$, 石油依存度 は $74 \%$ にも達して いる.

ii）近年の国際石油事情は，産油国の資源ナショナ リズムが高まり，1960 年代の原油過剩から一変して売 り手市場となった. エネルギ全体の需給の基調は，今 後む程度の差はあれ, 石油の動向の影響を受けてタイ 卜に推移しよう。

iii）国内では，環境対策の遅れで環境污染が進行, 電源立地などに制約を及ぼして，エネルギ供給の確保 に不安が生じてきた。

（2）エネルギ政策の課題国民福祉の向上に伴う 民生部門の需要增と, 適度の経済成長維持のために必 要なエネルギを確保するのが重要な課題である．安定 性と低廉性との関係は, 安定性を優先課題とせざるを 得ず，合理的な価格によりエネルギの確保を図る。
(1030 ページヘつづく) 